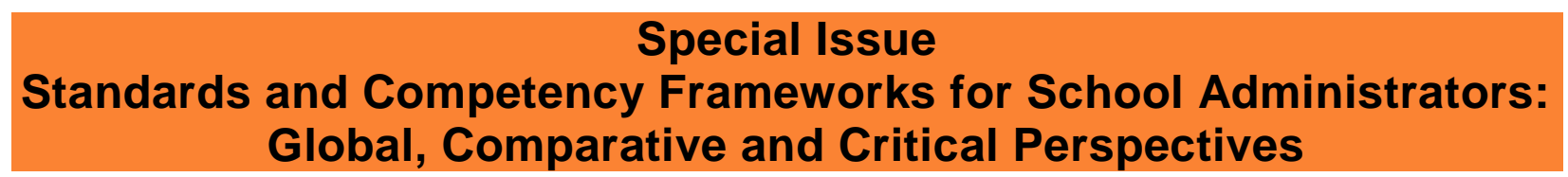

education policy analysis

\title{
archives
}

A peer-reviewed, independent, open access, multilingual journal

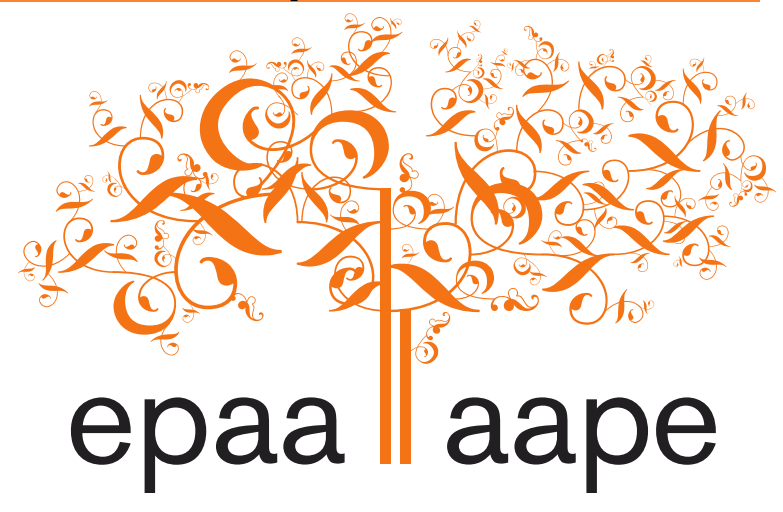

Arizona State University

\section{Comparative and Critical Analysis of Competency Standards for School Principals: Towards an Inclusive and Equity Perspective in Québec}

\author{
Julie Larochelle-Audet \\ ¿o \\ Marie-Odile Magnan \\ Université de Montréal \\ Maryse Potvin \\ \& \\ Emmanuelle Doré \\ Université du Québec à Montréal \\ Canada
}

Citation: Larochelle-Audet, J., Magnan, M.-O., Potvin, M., \& Doré, E. (2019). Comparative and critical analysis of competency standards for school principals: Towards an inclusive and equity perspective in Québec. Education Policy Analysis Archives, 27(112).

https://doi.org/10.14507/epaa.27.4217 This article is part of a special issue, Standards and Competency Frameworks for School Administrators: Global, Comparative and Critical Perspectives, guest edited by Augusto Riveros and Wei Wei. 
Abstract: This article presents the results of a comparative and critical study of the competency standards of Québec school administrators compared with seven other education systems within the Organisation for Economic Co-operation and Development (OECD). An inductive-type analysis has made it possible to identify the social categories targeted in the standards, the vision of school leaders as well as the competencies that are likely to help advance educational and societal goals of equity, inclusion, and social justice. Three contrasting perspectives emerge from this analysis. In Australia, California, and the United States, principals are explicitly encouraged to take action against structures and practices that undermine the educational success and social recognition of minority groups. In British Columbia and New Zealand, statements about social diversity focus more on the transformation of individual practices. Finally, in the standards of England, Texas and Québec, only a few generic statements referring to the differentiated needs of students and their success have been identified. They are instead characterized by a managerial approach oriented toward results that are measurable and cost controlled. In conclusion, a more in-depth analysis of the Québec standards opens the door to a new competency model and recommendations.

Keywords: Principal Competencies; inclusion; equity; social justice; comparative analysis

Análisis comparativo y crítico de los estándares de competencia para directores de escuela: Hacia una perspectiva inclusiva y equitativa en Québec

Resumen: Este artículo presenta los resultados de un estudio comparativo y crítico de los estándares de competencia de los administradores escolares de Québec en comparación con otros siete sistemas educativos dentro de la Organización para la Cooperación y el Desarrollo Económico (OCDE). Un análisis de tipo inductivo ha permitido identificar las categorías sociales a las que se dirigen los estándares, la visión de los líderes escolares y las competencias que pueden ayudar a avanzar en los objetivos educativos y sociales de equidad, inclusión y justicia social. Tres perspectivas contrastantes emergen de este análisis. En Australia, California y los Estados Unidos, se anima explícitamente a los directores a tomar medidas contra las estructuras y prácticas que socavan el éxito educativo y el reconocimiento social de los grupos minoritarios. En Columbia Británica y Nueva Zelanda, las declaraciones sobre diversidad social se centran más en la transformación de las prácticas individuales. Finalmente, en los estándares de Inglaterra, Texas y Quebec, solo se han identificado unas pocas declaraciones genéricas que se refieren a las necesidades diferenciadas de los estudiantes y su éxito. En cambio, se caracterizan por un enfoque gerencial orientado hacia resultados que son medibles y controlados por los costos. En conclusión, un análisis más profundo de los estándares de Québec abre la puerta a un nuevo modelo de competencia y recomendaciones.

Palabras-clave: Competencias principales; inclusión; equidad; justicia social; análisis comparativo

Análise comparativa e crítica dos padrões de competência para diretores de escolas: Em uma perspectiva inclusiva e de equidade no Quebec

Resumo: Este artigo apresenta os resultados de um estudo comparativo e crítico dos padrões de competência dos administradores das escolas de Quebec, em comparação com outros sete sistemas de ensino da Organização para Cooperação e Desenvolvimento Econômico (OCDE). Uma análise do tipo indutivo tornou possível identificar as categorias sociais direcionadas nos padrões, a visão dos líderes das escolas, bem como as competências que provavelmente ajudarão a avançar as metas educacionais e sociais de equidade, inclusão e justiça social. Três perspectivas contrastantes emergem dessa análise. 
$\mathrm{Na}$ Austrália, Califórnia e Estados Unidos, os diretores são explicitamente incentivados a agir contra estruturas e práticas que comprometem o sucesso educacional e o reconhecimento social de grupos minoritários. Na Colúmbia Britânica e na Nova Zelândia, as declarações sobre diversidade social se concentram mais na transformação de práticas individuais. Finalmente, nos padrões da Inglaterra, Texas e Quebec, apenas algumas declarações genéricas referentes às necessidades diferenciadas dos estudantes e seu sucesso foram identificadas. Em vez disso, são caracterizados por uma abordagem gerencial orientada para resultados mensuráveis e controlados por custos. Em conclusão, uma análise mais aprofundada dos padrões de Quebec abre as portas para um novo modelo de competência e recomendações.

Palavras-chave: Principais Competências; inclusão; justiça social; análise comparativa

\section{Comparative and Critical Analysis of Competency Standards for School Principals: Towards an Inclusive and Equity Perspective in Québec}

In pluralist societies with a liberal democratic system, the consideration of diversity within the education system is a fundamental issue. This issue goes hand in hand with respect for basic rights, including the right to education. Everyone should have access to quality education in order to promote the equitable distribution of goods and resources as well as dignity in social interactions (Dei \& al., 2000; Shields, 2012). In the area of school administration, a growing body of work is advancing the concept of leadership in relation to equity, inclusion, and social justice (Hunt 2005; Thibodeau \& al., 2016). Several studies reveal that school principals have a significant leadership position that can support changes in the school environment aimed at implementing and sustaining inclusive practices (Bouchamma \& Tardif, 2011; Norberg, 2017; Pereira Braga \& Magnan, 2015; Riehl, 2000). The type of leadership exercised by school principals seems to have an influence on the overall daily activities of the school aimed at including all students (Ryan, 2012; Thibodeau et al., 2016). Within comparable school populations, the principals who take a leadership role in promoting social justice, for example, see a positive effect on the educational success of students living in poverty (Archambault \& Garon, 2013; Archambault \& Richer, 2014). This literature argues that principals and vice-principals ${ }^{1}$ have a critical role to play as leaders in dealing with the dynamics that marginalize specific persons and communities.

The important role played by administrators in the implementation of a more equitable, inclusive and fair educational system, however, is hampered by the lack of administrator training for this purpose in several countries, including Canada (Gélinas Proulx, IsaBelle, \& Meunier, 2014; Khalifa, Gooden, \& Davis, 2016; Tuters \& Portelli, 2017; Young, Madsen, \& Young, 2010). Similar findings on the training offered in Québec (Borri-Anadon, Potvin, Longpré, Pereira Braga, \& Orange, 2018; Ouellet, 2010) led to the creation in 2016 of a group composed of education leaders who had as a common objective the improvement of the introductory and ongoing training of school administrators in order to better develop their competencies to incorporate social diversity in a perspective of equity, inclusion, and social justice. To that end, the Working Group on Competencies and Training for Administrators in Equity and Diversity (Groupe de travail sur les compétences et la formation des directions en matière d'équité et de diversite) has developed a new competency

\footnotetext{
${ }^{1}$ In this paper, the nouns administrator or principal include both principal and vice-principal.
} 
model for decision-makers involved in training, coaching, supervising and evaluating the practices of school principals. ${ }^{2}$

This article presents the results of a comparative analysis of eight sets of administrator competency standards that inspired the creation of this model. A critical conceptual and theoretical approach was adopted in order to conduct an analysis in which the concepts of diversity, social categories, minoritized groups, equity, inclusion, and social justice are interlocked. Before presenting the results, we describe the methodological approach adopted as well as the corpus of standards analyzed. The three questions that guided our work served to structure the presentation of the results, relating respectively to the identified social categories, the vision of valued leaders, and the proposed competencies. The article concludes with a critical discussion of the consideration of diversity in a perspective of equity, inclusion, and social justice in the competency standards aimed at school administrators. Before entering the heart of the analysis, we first draw some conclusions on the state of equity, inclusion, and social justice in education in order to situate the context under study, in particular with regard to Québec institutions.

\section{Background}

In Canada, education is a provincial jurisdiction. Québec has its own ministry of education which is responsible for the organization, delivery and evaluation of education from the elementary to postsecondary level. In 2017, the Québec Ministry of Education adopted a new education policy which had an overarching vision of the implementation of "Inclusive educational settings focused on success for all, supported by their community, where people learn to be civic-minded, creative, competent, responsible, open to diversity and fully engaged in social, cultural and economic life in Québec" (Ministry of Education and Higher Education, 2017, p. 26). This policy reiterates the right to education for all, as well as the principles of equality and social justice that guided the democratization of the Québec education system in the late 1960s. By virtue of international and national standards including the Education Act (2019), there is no justification for depriving certain individuals or communities of basic needs such as education. This imperative is part of the right to equality, which has been protected since 1975 by the Québec Charter of Human Rights and Freedoms (2016).

Despite the above legislative provisions, the implementation of equal rights to education has encountered several pitfalls, which led the Conseil supérieur de l'éducation (2016) to urge Québec society, political authorities, and the leaders of educational institutions to steer the course back to equity in education to prevent the progress made in recent decades from being compromised. In particular, the council invited stakeholders to examine how the operation of the education system acts to perpetuate certain inequalities. In Québec, as in other societies with democratic institutions, the forms of organization and regulation of the educational system support a meritocratic conception of education that tends to reproduce inequalities and exclusion (Conseil supérieur de l'éducation, 2010, 2016; Maroy \& Kamanzi, 2017).

The stratification of the academic pathways offered to students, the separation of students according to socio-economic profile and their academic performance, as well as the competition

\footnotetext{
${ }^{2}$ Acknowledgments: The authors wish to acknowledge the contribution of the members of the group, and thank Anastasie Amboulé Abath, Andréanne Gélinas Proulx, Philip Howard and Lise-Anne St-Vincent for their contribution to the writing of the report arising from the work of this group, which was the inspiration for this paper (Larochelle-Audet et al., 2018). The article was translated from French to English by Peter Wheeland. The authors would like to thank him for his valuable contribution to this paper.
} 
between educational institutions contribute to this meritocratic conception of education (Dubet, Duru-Bellat, \& Vérétout, 2010; Kamanzi \& Pilote, 2016; Marcotte-Fournier, Bourdon, Lessard, \& Dionne, 2016). Inequalities and injustices can also result from apparently neutral and egalitarian policies, rules, decisions, and educational practices, including standardized tests, screening and grading, the organization of academic pathways and transitions (Borri-Anadon, 2014, 2016; Commission of Human Rights and Youth Rights, 2011; Dhume-Sonzogni, 2014; Magnan \& Vidal, 2015), the selection of school personnel (Larochelle-Audet, 2019; Ryan, Pollock, \& Antonelli, 2009), and the choice of curricula content (Apple \& Beane, 2007; Sleeter \& Grant, 2009).

Several policies and reports published in Québec have recognized that the training of principals and other education professionals is one of the pillars for the implementation of practices that take social diversity into account in the education system (Commission of Human Rights and Youth Rights, 2009, 2011; Ministry of Education, 1998; Ministry of Immigration and Cultural Communities, 2008). Training is an ideal opportunity for the administrators to finally engage in a more comprehensive reflection on the role of justice and democracy as fundamental aspects of leadership in education (Magnan, Gosselin-Gagné, Charrette, \& Larochelle-Audet, 2018; Shields, 2012).

It has been mandatory in Québec since 2001 to complete a university graduate program with a minimum of 30 credits in leadership in order to practise the profession of principal or viceprincipal of an educational institution. ${ }^{3}$ In a context of the professionalization of the management role, the competency-based approach occupies an important place in the structure of these training courses, and in particular in specialized graduate degrees in the administration of education (IsaBelle, Meunier, \& Gélinas Proulx, 2016). Although it has no prescriptive value, the competency standards for school leadership training established in 2008 by the Ministry of Education, Recreation and Sports is an important reference point for the training offered in universities and school boards (Bernatchez, 2011; D’Arrisso, 2013).

Inspired by these standards, some universities and school boards have developed their own competency standards to better reflect their own administrative contexts and missions (training, supervision, regulation, professional development). These frames of reference therefore also serve as tools and levers for administrators in their professional development and their evaluation, supervision, and support within their educational institutions. Throughout their career, the standards guide administrators in the exercise of their responsibilities and in their autonomy to adopt actions and initiatives relevant to the context and the goals they set (Legendre, 2008). The importance of these standards in the training, supervision and professional development of administrators (IsaBelle et al., 2016) grant them an essential role in contributing to equity, inclusion, and social justice in schools.

\section{Conceptual and Theoretical Approach}

The reflections of the Working Group on Competencies and Training for Administrators in Equity and Diversity were conducted using a two-level conceptual and theoretical approach. From the outset, the members of the Group tasked themselves to take into account human and social diversity in all its dimensions. This report, therefore, does not focus specifically on one group or another, but rather focuses on inequalities and exclusion in the recognition and distribution of

\footnotetext{
${ }^{3}$ University training must be completed before or during the first five years of practice. It is possible to start exercising the profession as soon as the first six credits (two university courses) are successfully completed. Individuals wishing to practice must also hold a teaching licence and have a minimum of five years of relevant experience.
} 
educational resources to socially minoritized groups. To guide the work, the members of the Group identified three concepts with concomitant goals to deal with inequality and exclusion in education: equity, inclusion, and social justice.

\section{Diversity, Social Categories, and Minoritized Groups}

Human diversity can be defined in the educational context as the expression of a variety of student profiles that combine several characteristics, preferences, experiences, or needs (Prud'homme, 2007) that are uniquely interlocked in the life of each person. Human diversity is not a problem - nor an asset - it is a statement of fact: it exists, in all its myriad forms. As French materialist feminists notably theorized (e.g. Delphy, 2013), it is the negative social construction of characteristics, preferences, experiences, or needs that makes them a problem in a given context - time, place, social and political issues, rapport with authority - used to legitimize processes of exclusion, exploitation and inferiorization of certain groups of people. In other words, the problem is not human diversity, but how society and humanity treat it (Delphy, 2013). The concepts of social diversity and social differences are advanced through practices, policies, and ideologies that impose and maintain rank, privilege, and the unequal distribution of power, prestige, and property in society (Juteau, 2003).

The concept of diversity has a generally positive connotation, encouraging its use in different spheres of social life. From a critical point of view, however, this concept functions as a euphemism (Ahmed, 2009; Ricci, 2015). It draws attention to "good" actions, such as best practices, avoiding conflicting areas and disturbing realities such as inequality, domination, and discrimination, and minimizing the history of social movements in advancing individual rights and freedoms. To limit the depoliticization of these social issues, the Group members opted for the concept of minoritized group in their work (Guillaumin, 2002). Unlike diversity, this concept highlights the social hierarchy of individual and collective identities for the purpose of domination (Potvin \& Pilote, 2016). In a way that is both historicized and contextualized, certain identities are constructed as the norm and others as being on the margins of societies. Physical or sociocultural markers of real or imagined diversity - colour, language, gender, socio-economic condition, etc. - are used to construct social categories by which individuals and groups are excluded and inferiorized in terms of power. The construction of social categories - another important concept in this study - comes from the biologization of social thought that masks beneath a belief in "natural" differences the power relationships at the origin of the social division between the groups (Guillaumin, 2002). These social categories do not exist per se, but are constructed in societies to legitimize an unequal distribution of material and symbolic resources among groups.

Although this puts minority and majority in opposition, the concept does not refer to a binary reality (Gélinas Proulx \& Shields, 2016; Shields, 2012). A group can be minoritized, "othered", and oppressed even if it is composed of a large number of individuals. Minoritization processes are (re)constructed according to the context and power relations at issue, but also according to the intersection of different social categories and systems of oppression, such as sexism, racism, linguicism, homophobia, ableism, or transphobia (Collins \& Bilge, 2016). As summarized by Fraser (1998), oppression does not operate in a compartmentalized way. Rather, it should be approached as a global dynamic within which acts of injustice mesh indiscriminately with gender, ethnocultural background, class position, and sexual orientation (Fraser, 1998, pp. 17-18). In the school environment, the interlocking of social categories and systems of oppression is reflected, in particular, in the overrepresentation of certain groups of students in special education programs and among students subject to disciplinary measures. For example, several studies in the United States and Canada show how ableism and racism intersect within the school system (Borri-Anadon, 
2014, 2016; Commission on Human Rights and Youth Rights, 2011; Crenshaw, Ocen, \& Nanda, 2015; James \& Turner, 2017). These studies provide an intersectional reading of the pathways and barriers faced by students similar to those favoured by the Working Group on Competencies and Training for Administrators in Equity and Diversity.

\section{Equity, Inclusion, and Social Justice}

In an effort to address the processes and practices by which groups and individuals are marginalized in schools, the members of the Working Group on Competencies and Training for Administrators in Equity and Diversity aspire at transforming educational institutions rather than the people who attend them. Group members reject deficit-driven concepts that primarily attribute educational and social inequalities to a person's individual characteristics, background, presumed lack of potential, or inability to develop certain competencies (Ainscow \& Miles, 2008; AuCoin \& Vienneau, 2015; Borri-Anadon, 2016). The study instead relies on critical concepts that question the functioning of the education system in order to understand how certain practices and structural processes compromise the rights and development of people from minoritized groups, including students, their families, and school personnel (Dei et al., 2000; Potvin et al., 2015). These practices and processes reproduce social inequalities and hinder any project for democratization and social justice. The members of the Group therefore favour a systemic perspective and concepts of equity, inclusion, and social justice in education that call for the introduction of a transformative leadership (Shields, 2012).

As summarized by European Group of Research on Equity of the Educational Systems (2005), "fair educational system is a system that treats all pupils as equals and which aims to encourage a fair society, in which essential assets are distributed in accordance with the rules of justice and which encourages cooperation on an equal footing" (pp. 13-14). Equity therefore goes beyond the concept of formal equality or the meritocratic equality of opportunity, according to which the gifts, talents, or aptitudes of individuals define the level or threshold to be reached in the education system. Equity also moves away from equal treatment, where all students receive the identical treatment. Instead, equity provides differential treatment depending on the needs of students (which could be called real equality) to mitigate the effect of school practices and processes that place students at a disadvantage because of their social status or capacities (Conseil supérieur de l'éducation, 2016; Magnan \& Vidal, 2015). Equity in education aims to correct inequalities that unfairly affect some students and instead aspires to create real equality.

The inclusive approach also pursues a real equality, one of results, achievements, and educational success (Potvin, 2013). Long associated with the educational integration of students with disabilities, it is now expanding to take into account the reality of all underrepresented and marginalized students in the education system (Borri-Anadon, Potvin, \& Larochelle-Audet, 2015). In addition to ensuring the right to education, the inclusive teaching-learning process must allow each student to receive an education that reflects their (social) identities and is adapted to her/his experiences, personal characteristics, and particular needs (AuCoin \& Vienneau, 2015). This concept of inclusion prescribes a transformation of school structures, moving away from school integration initiatives that seek to prepare learners with disabilities - or any other negatively constructed difference or identity in society - to live and work in the most normal contexts possible. It proposes to transform institutions, especially schools, to allow the contribution of all individuals, in and with their differences (Potvin, 2013).

Expanding the perspective even further, Dei et al. (2000) consider inclusive education as a transformative social project that involves the redistribution of power, especially with students: 
The critical approach to inclusive schooling has a transformative educational and social agenda. It focuses on the asymmetrical power relations between the social groups and the system and seeks to redistribute power to ensure fair representation, not only of the actors themselves, but also of the subjects of knowledge production. It seeks to equip individuals with knowledge and skills to confront their own biases and prejudices, and work for social change. In the process, it legitimizes oppositional and subjugated voices while engendering an educational atmosphere in which all youth can challenge and resist the structural forces that continually reproduce social oppression and inequality. (p. 15)

The goals of inclusive education largely coincide with those of social justice, which is "based on the belief that each individual and group within a given society has a right to equal opportunity, civil liberties, and full participation in the social, educational, economic, institutional, and moral freedoms and responsibilities of that society" (Ministry of Education, 2014, p. 90). Redistribution and recognition are two channels indissociable from the idea of social justice. While redistribution aims for a fair balance in the distribution of available goods and resources, recognition supports respect for personal and collective differences that mark individuals in their relationships to others. They aspire to a world where integration of the dominant cultural norms of the majority would no longer be a prerequisite for equal treatment; a world where minorities could live and have their differences fully and uncompromisingly accepted, be they ethnic, "racial," cultural, or sexual (Fraser, 1998, p. 9).

A growing body of work on leadership styles is rallying to the concept of leadership in relation to equity, inclusion, and social justice (Hunt, 2005). Among these kinds of leadership are inclusive leadership, transformative leadership, and leadership for social justice. These leadership styles generally support a similar goal, that is achieving a school culture that respects diversity, where social justice and equity play a central role (Thibodeau \& al., 2016, p. 60). The variety of leadership styles involved depends on and bears witness to the variety of contexts in which the administrators operate. The principles of these leaderships and their levers of action are enlightening for the development of the competency model intended to guide managers in their work, because they concord with the conceptual and theoretical approach favoured by the Group. They involve personal reflective analysis, systemic analysis of the institution's culture, and a confrontation of the inequalities experienced by certain individuals within the educational community in and beyond the school environment (Cooper, 2009; Wilson, 2014). To put these leaderships into practice, administrators must develop a critical understanding of the social inequities experienced by the communities served by the school and the socio-historical conditions in which they emerged (DeMatthews \& Mawhinney, 2014; Shields, 2012). School leaders reject individualistic and hierarchical conceptions of the distribution of decision-making power in favour of more horizontal conceptions with the different actors of the educational community, and in particular students (Ryan, 2012; Theoharis \& Causton-Theoharis, 2008). To increase the participation and decisionmaking rights of students and their families in the school, principals are actively engaged in the deconstruction of deficit-based thinking and in the construction of new inclusive frames of reference that support them (Ainscow \& Miles, 2008).

\section{Methodology}

With the aim of formulating proposals to improve the Québec standards and the training of school administrators to take into account social diversity in a perspective of equity, inclusion, and social justice, we have conducted a comparative analysis of eight competency standards for school 
administrators. The analysis aims to study the ways - concepts, viewpoints, emphasis - in which the standards address social diversity.

\section{Selection of Reference Standards and Analytical Approach}

The standards analyzed within this study were chosen from among 11 standards of Organisation for Economic Co-operation and Development (OECD) countries previously studied by Pont (2013). In accordance with the Group's main goals, we have selected only the standards - or their updated versions - that concern social diversity, equity, inclusion or social justice. Among those studied by Pont (2013), we chose the standards that included at least one of the following two competencies: "addresses the special needs of pupils and the community" (p. 54) and "promotes values of democracy, equity, respect and diversity" (p. 56). These are the only competencies indexed by Pont (2013) that correspond to our criteria.

The chosen standards were those of Australia (Australian Institute for Teaching and School Leadership, 2014), British Columbia (British Columbia Principals' \& Vice-Principals' Association, 2015), California (Commission on Teacher Credentialing, 2014), England (Department of Education, 2015), New Zealand (Ministry of Education of New Zealand, n. d.) the United States (National Policy Board for Educational Administration, 2015), and Texas (Texas Education Agency, 2014). We have also included in the analysis Québec's competency standards for school administrators (Ministry of Education, Recreation and Sports, 2008), even though Pont's 2013 analysis indicates that it includes neither the competencies related to the needs of the students nor the values relating to the democracy, equity, respect, or diversity. This inclusion was instead guided by the objectives of the Group that conducted the analysis, aimed in particular at developing a new competency model for Québec school leaders.

The analysis of the eight standards was conducted on the basis of three questions formulated to cohere to the preferred conceptual and theoretical approach. The first question was this: Which social categories are named in the competency standards? Its aim was to circumscribe the social categories explicitly named in the eight standards studied. Drawing inspiration from the grounds for discrimination cited by the Québec Charter of Rights and Freedoms ${ }^{4}$ (2016), we identified the terms used in the competency outlines - including their descriptions and components, if any - of the eight standards.

The second analytical question was the following: What competency goals are set in the standards for the consideration of social diversity in a perspective of equity, inclusion, and social justice proposed for school leaders? This question enabled us to examine the vision of school leaders as prescribed in the eight skill standards. The corpus was slightly expanded for this second question in order to take into account the vision element outlined in the contextualizing chapters of the standards, and not only in the skill sections. As stated by McShane and Benabou (2008), vision establishes a future scenario that brings people together and motivates them to do everything possible to achieve the objectives that result (p. 573). Vision constitutes a structuring element in the competency-based standards approach, where it guides the action to be taken.

The analysis of the standards' visions was based on two objectives earlier defined by the Group on Competencies and Training for Administrators in Equity and Diversity to take into account social diversity in a perspective of equity, inclusion, and social justice: 1) to make the school an environment in which the stakeholders of the educational community can act against inequalities,

\footnotetext{
${ }^{4}$ The Charter prohibits any discrimination or preference "based on race, colour, sex, gender identity or expression, pregnancy, sexual orientation, civil status, age except as provided by law, religion, political convictions, language, ethnic or national origin, social condition, a handicap or the use of any means to palliate a handicap" (2016).
} 
discriminations and social exclusion to create a more just and egalitarian inclusive society; and 2) to establish, with the school staff, conditions that promote the educational success of all students, taking into account minoritized groups while respecting their rights, identities, experiences and individual and collective needs.

The first objective reflects the principles of equity, inclusion, and school justice for all those involved in school space, as well as their objective of social transformation. The second mainly targets students, their recognition within the school environment, and their educational success. ${ }^{5}$ While specific as to the role and mandates of the administrators, these two goals are inspired by those developed by Potvin \& al. (2015) and are consistent with those in the Policy Statement on Educational Integration and Intercultural Education (Ministry of Education, 1998).

The third question relating to the corpus was the following: What competencies or components may contribute to the consideration of social diversity from the perspective of equity, inclusion, and social justice? The purpose of this question was to identify abundant competencies in this sense and then to extract emerging analytic categories. This question created the opportunity to conduct a general inductive analysis (Blais \& Martineau, 2006) from the eight administrator competency standards selected. In terms of the analysis that involved several members of the Working Group on Competencies and Training for Administrators in Equity and Diversity, five broad analytical categories emerged. Each addresses the consideration of social diversity from different dimensions of the work of school administrators: academic climate, pedagogical leadership, resource and system management, family and community relations, and professional ethics and development. It should be noted that each segment analyzed - whether a statement of competencies or a component - has been classified in only one analytical category.

\section{Limits and Characteristics of the Corpus}

This corpus has certain limits. Since the choice of standards was made from an analysis conducted for the OECD, only school systems of member countries of this organization are considered. By limiting the analysis to Anglo-occidental countries, our study may contribute to the convergence and dominance of leadership theory from these countries (Magno, 2013). Despite our goal of working for equity, inclusion and social justice, this could also serve as a "policyscape" that roots ideology and economic values in education reforms at the international level (Carney, 2009). Other standards that take into account social diversity and pursue goals of equity, inclusion, and social justice could have been analyzed, among which those of other Canadian provinces. The selected documents were sometimes difficult to compare because of their varied formats. The standards of Texas and New Zealand are embedded in legal-political documents. The Texas standards constitute a section of the state's educational act, while in New Zealand there are three standards enshrined in the collective agreements of elementary schools (R1), secondary schools (R2), or "area schools" (R3) principals. These standards - as accessed online on November 1, 2016 - are also succinct, respectively taking up just five and two pages respectively. The other six standards

\footnotetext{
${ }^{5}$ Educational success encompasses the three missions of the school (to qualify, instruct, socialize) contained in the Education Act and thus covers academic success: "It includes success in school, but goes beyond obtaining a diploma or qualification by taking the person's overall intellectual, cognitive, affective, social and physical potential into account starting in early childhood" (Ministry of Education and Higher Education, 2017, p. 26).

${ }^{6}$ The Area Schools are most often found in rural, geographically isolated areas, where distances and the state of the road network limit students' movements for schooling and where the school-age population does not justify having a separate primary and secondary school.
} 
constitute or are composed of separate orientation documents. Their length varies significantly, ranging from 11 to 60 pages. $^{7}$

The reference standards also reveal differences in the elements used to classify, describe, and clarify the competencies. In order to properly situate each of the standards and to increase the reliability of the results of the analysis, their main characteristics are summarized and presented in Table 1. The concepts used in the documents consulted to examine the different constitutive elements of the standards vary considerably. Comparative analysis, however, leads us to offer a common terminology. For the sake of consistency and understanding, we use the term domain in the following sections to refer to groups of competencies (e.g., culture, pedagogy, moral stewardship). The term competency designates main statements (the heart), while that of component refers to the elements that clarify, detail, or describe.

Table 1

Main characteristics of the standards analyzed

\begin{tabular}{|c|c|c|c|c|}
\hline Standards & $\begin{array}{c}\text { Pages } \\
N\end{array}$ & $\begin{array}{c}\text { Domains } \\
N\end{array}$ & $\begin{array}{c}\text { Competencies } \\
N \\
\end{array}$ & $\begin{array}{l}\text { Components } \\
\text { Types }\end{array}$ \\
\hline Australia (2014) & 29 & $2^{\mathrm{a}}$ & 8 & Description, profile \\
\hline British Columbia (2015) & 48 & 4 & 9 & $\begin{array}{c}\text { Action statement, reflective } \\
\text { question }\end{array}$ \\
\hline California (2014) & 12 & NA & 6 & Element, indicator examples \\
\hline England (2015) & 11 & 4 & 24 & NA \\
\hline New Zealand (n.d.) & 2 & 4 & 26 to $28^{\mathrm{b}}$ & NA \\
\hline Québec (2008) & 60 & 4 & $10^{c}$ & $\begin{array}{l}\text { Key action, professional } \\
\text { situations, expected results }\end{array}$ \\
\hline Texas (2014) & 5 & NA & 5 & $\begin{array}{l}\text { Knowledge/expertise, } \\
\text { indicator }\end{array}$ \\
\hline United States (2015) & 27 & NA & 10 & Element \\
\hline
\end{tabular}

a The Australia standards also includes four "leadership emphasis lenses" which were not considered in the analysis. ${ }^{\mathrm{b}}$ The core number varies according to the standards: for principals of primary (R1), high school (R2) or area schools (R3). ${ }^{c}$ The Québec standards are also composed of six transversal components, cutting across each of the 10 competencies.

\section{Results of the Standards Analysis}

Inductive analysis identifies the social categories targeted in the eight competency standards, the vision of the school leader as well as the competencies likely to promote the educational and societal goals of equity, inclusion, and social justice. The results of the analysis illustrate the more or

\footnotetext{
${ }^{7}$ The longest standards have some peculiarities. The documents from Australia and Québec give more space to contextual chapters about the education system, society, and ministerial orientations. For its part, BC's Terms of Reference provides a glossary of concepts used as well as self-assessment grids for the branches. Finally, that of the United States explains the use to be made of the frame of reference from the theory of action.
} 
less detailed consideration of the issues inherent in diversity at school as well as the variety of perspectives adopted.

\section{Analysis of Social Categories Named in the Standards}

The first question made it possible to identify and to classify the social categories explicitly named in the competency standards. The eight standards analyzed valued educational success, even the well-being of all students. The standards of England, Texas, and Québec are limited; that is, they do not explicitly identify any social category among their competencies and components. Some social categories are included in the five other standards (Australia, California, British Columbia, United States, and New Zealand). The social categories identified in the corpus have been grouped into six analytical categories, referring to six types of social relations by which groups are excluded and inferiorized in terms of power (Guillaumin, 2002; Potvin \& Pilote, 2016): capacity, special need, disability; minority culture, language, race, religion; First Nations, Indigenous; social class, economic poverty; gender; and sexual orientation. The social categories named in each standard are summarized in Table 2.

Table 2

Comparative table of social categories named in the standards

\begin{tabular}{|c|c|c|c|c|c|c|}
\hline \multirow[b]{2}{*}{ Standards } & \multicolumn{6}{|c|}{ Social categories } \\
\hline & $\begin{array}{l}\text { Capacity, } \\
\text { special } \\
\text { need, } \\
\text { disability }\end{array}$ & $\begin{array}{l}\text { Minority } \\
\text { culture, } \\
\text { language, } \\
\text { race, } \\
\text { religion }\end{array}$ & $\begin{array}{c}\text { First } \\
\text { Nations, } \\
\text { Indigenous }\end{array}$ & $\begin{array}{l}\text { Social } \\
\text { class, } \\
\text { economic } \\
\text { poverty }\end{array}$ & Gender & $\begin{array}{c}\text { Sexual } \\
\text { orientation }\end{array}$ \\
\hline Australia & $\mathrm{x}$ & $\mathrm{x}$ & $\mathrm{x}$ & & & \\
\hline British Columbia & $\mathrm{x}$ & $\mathrm{x}$ & & $G^{a}$ & G & \\
\hline California & $\mathrm{x}$ & $\mathrm{x}$ & & $\mathrm{x}$ & & \\
\hline \multicolumn{7}{|l|}{ England } \\
\hline New-Zealand ${ }^{\mathrm{b}}$ & $\mathrm{x}$ & $\mathrm{x}$ & $\mathrm{x}$ & & & \\
\hline \multicolumn{7}{|l|}{ Québec } \\
\hline \multicolumn{7}{|l|}{ Texas } \\
\hline United States & $\mathrm{x}$ & $\mathrm{x}$ & & $\mathrm{x}$ & $\mathrm{x}$ & $\mathrm{x}$ \\
\hline \multicolumn{7}{|c|}{ 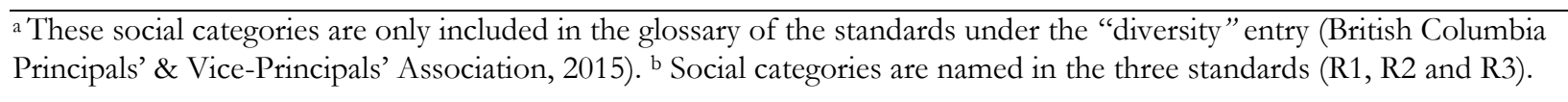 } \\
\hline \multicolumn{7}{|c|}{$\begin{array}{l}\text { Social categories related to capacity, special needs, and disabilities are named in the standards } \\
\text { of Australia, California, British Columbia, the United States and New Zealand. Most often, these are } \\
\text { students with "special needs" or disabilities or who are "at risk" or failing. In the Australia standards, } \\
\text { students with special aptitudes ("gifted") are also identified. Social categories relating to minority } \\
\text { cultures, languages, race, and religion or spirituality are also named in these five competency } \\
\text { standards. Cultural and linguistic differences, affiliations or cultural and linguistic communities are } \\
\text { mentioned, as are religious differences in the case of the Australia standards, and racial distinctions } \\
\text { in California. Only the Australia and New Zealand standards deal more specifically with Indigenous }\end{array}$} \\
\hline
\end{tabular}


communities and the educational issues affecting them, even though the majority of the eight sets of standards analyzed are in colonized territories formerly occupied by Indigenous peoples.

Three standards also refer to social categories related to social class and economic poverty. Class is referenced in the U.S. standard, as are students from disadvantaged socio-economic backgrounds in California's, and students' socio-economic needs in the British Columbia standards. The U.S. standard is the only one to address social categories related to sexual orientation. It also deals with gender, as does British Columbia's.

The angle from which these social categories are approached in these five standards varies significantly, but they are nevertheless most often associated with the students themselves and their needs. In the glossary of the British Columbia standards, it is for example stipulated that discussions about diversity require the recognition of the variety of student needs, including those related to ethnicity, language, socio-economic class, disabilities, and gender (British Columbia Principals' and Vice-Principals' Association, 2015, p. 32).

While the U.S. standards focus on students, they offer a much more critical perspective in which the social construction of categories is reflected. One element of the standards is particularly eloquent in this respect, calling on administrators to confront and alter institutional biases through which students are educationally marginalized. In the Californian standards, we also see a more critical language which is not focused on student deficits. In a number of instances, social categories are linked to sources of discrimination and exclusion from school rather than to the needs of students. The California document also discusses underrepresented communities, which relate to issues of power. In the Australia standards, the social categories associated with languages, cultures and Indigenous communities are most often discussed in terms of their richness.

\section{Vision of School Leaders in the Standards}

The second question allowed us to analyze the vision of the school leader proposed in the eight sets of standards. The competency standards for school principals generally outline an overall vision and values to guide school administrators in the exercise of their functions and their leadership in the educational community. In the standards of England, California, British Columbia, the United States, New Zealand, and Texas, the school leader's vision is condensed into the first skill spelled out. In the standards of Australia and Québec, the vision of the school leader is instead discussed in a section providing contextualization and, for the Australia standards, in a "Leadership Requirement" called Vision and Values (Australian Institute for Teaching and School Leadership, 2014). It is in the Australia standards that the vision of the school leader is the most detailed.

The objective behind this question was to see to what extent the vision of each set of standards encompasses the consideration of social diversity in a perspective of equity, inclusion, and social justice. More specifically, we sought to identify the presence of the two previously determined aims. Table 3 synthesizes the objectives identified in the standards analyzed. 
Table 3

Comparative Table of School Leaders' Visions

Aims

\begin{tabular}{cll}
\hline Create a space in which educational & $\begin{array}{l}\text { Provide all students, both young and } \\
\text { community leaders can act to counter } \\
\text { inequalities, discriminations and social } \\
\text { exclusions to create a more just and } \\
\text { egalitarian society }\end{array}$ & $\begin{array}{l}\text { for educational success while } \\
\text { respecting their individual and } \\
\text { collective rights, identities, experiences } \\
\text { and needs }\end{array}$ \\
\hline \multicolumn{1}{c}{ Australia } & $\mathrm{x}$ & $\mathrm{x}$ \\
$\begin{array}{c}\text { British Columbia } \\
\text { California } \\
\text { England }\end{array}$ & & $\mathrm{x}$ \\
New Zealand & & $\mathrm{x}$ \\
$\begin{array}{l}\text { Québec } \\
\text { Texas }\end{array}$ & & \\
United States & & \\
\hline
\end{tabular}

Overall, the analysis indicates that competency goals aimed at taking social diversity into account in a perspective of equity, inclusion, and social justice are rarely reflected in the vision of the school leader as proposed in the eight sets of standards analyzed. Only the visions proposed in the Australia, California, and U.S. standards reflect, in some respects, the goals of equity, inclusion, and social justice in education. In the Californian standards, the school leader vision for equity, inclusion, and social justice in education is this: "Leaders shape a collective vision that uses multiple measures of data and focuses on equitable access, opportunities, and outcomes for all students" (Commission on Teacher Credentialing, 2014, p. 4). The U.S. standards set the following objective:

"Articulate, advocate, and cultivate core values that define the school's culture and stress the imperative of child-centered education; high expectations and student support; equity, inclusiveness, and social justice; openness, caring, and trust; and continuous improvement" (National Policy Board for Educational Administration, 2015, p. 9). The vision proposed in these two sets of standards is more in line with the second purpose, centred on students and their educational success.

A vision for equity, inclusion, and social justice is reflected in several parts of Australia's professional standards (Australian Institute for Teaching and School Leadership, 2014). It is particularly highlighted in the section on the role of management in the 21 st-century school, where is presented as "Inclusive Australia":

All principals have the responsibility to work with members of the school community to ensure a knowledge and understanding of the traditional rights, beliefs and culture of Australia's Indigenous peoples.

All students in all communities, including Indigenous, multi-cultural and multi-faith communities, across metropolitan, rural, regional and remote Australia, have the right to an education that ensures they become creative, confident, active, informed learners and citizens. This same right extends to students at risk and those of differing needs and abilities (Australian Institute for Teaching and School Leadership, 2014, p. 7).

This vision statement, which is much more extensive than those identified in the other standards, encompasses the two competency goals for taking into account social diversity in a perspective of 
equity, inclusion, and social justice. On the one hand, the responsibility of administrators for the recognition and understanding of the traditional rights, beliefs, and culture of Indigenous peoples is emphasized (purpose 1). On the other, the right to education of all students is evoked, including Indigenous students, minority ethnocultural or religious communities or those with special needs and abilities (purpose 2).

\section{Competency Analysis and Standards Components}

The third question identified and categorized the competencies and components that can contribute to the inclusion of social diversity in a perspective of equity, inclusion, and social justice. The eight reference standards examined propose various competencies and components that can contribute to taking into account social diversity in a perspective of equity, inclusion, and social justice. A general inductive analysis of the competences and components of this corpus led to the emergence of five analytical categories, described in the following paragraphs. Table 4 summarizes the analysis for each analytical category and standard.

Table 4

Comparative Table of Competencies and Standards Components

\begin{tabular}{|c|c|c|c|c|c|}
\hline \multirow[b]{2}{*}{ Standard } & \multicolumn{5}{|c|}{ Analytical category } \\
\hline & $\begin{array}{c}\text { Create a } \\
\text { climate where } \\
\text { human and } \\
\text { social diversity } \\
\text { is recognized } \\
\text { and respected }\end{array}$ & $\begin{array}{c}\text { Develop } \\
\text { leadership and } \\
\text { non-deficit } \\
\text { oriented } \\
\text { pedagogical } \\
\text { practices that } \\
\text { are tailored to } \\
\text { the realities } \\
\text { and needs of } \\
\text { people }\end{array}$ & $\begin{array}{c}\text { Guide } \\
\text { practices and } \\
\text { transform } \\
\text { structures to } \\
\text { counter } \\
\text { inequalities } \\
\text { and disparities } \\
\text { between } \\
\text { groups of } \\
\text { students }\end{array}$ & $\begin{array}{l}\text { Know, value } \\
\text { and engage } \\
\text { students' } \\
\text { families and } \\
\text { communities, } \\
\text { especially } \\
\text { those who are } \\
\text { under- } \\
\text { represented }\end{array}$ & $\begin{array}{l}\text { Promote and } \\
\text { adopt an } \\
\text { honest and } \\
\text { critical } \\
\text { professional } \\
\text { action } \\
\text { reflecting } \\
\text { principles of } \\
\text { equity, } \\
\text { inclusion, and } \\
\text { social justice }\end{array}$ \\
\hline Australia & $\mathrm{x}$ & $\mathrm{x}$ & & $\mathrm{x}$ & $\mathrm{x}$ \\
\hline $\begin{array}{l}\text { British } \\
\text { Columbia }\end{array}$ & $\mathrm{x}$ & & $\mathrm{x}$ & & $\mathrm{x}$ \\
\hline California & $\mathrm{x}$ & $\mathrm{x}$ & $\mathrm{x}$ & $\mathrm{x}$ & $\mathrm{x}$ \\
\hline England & & $\mathrm{x}$ & & $\mathrm{x}$ & \\
\hline New Zealand & $\mathrm{x}$ & $\mathrm{x}$ & & $\mathrm{x}$ & $\mathrm{x}$ \\
\hline Québec & & $\mathrm{x}$ & $\mathrm{x}$ & & $\mathrm{x}$ \\
\hline Texas & & & $\mathrm{x}$ & & \\
\hline United States & $\mathrm{x}$ & $\mathrm{x}$ & $\mathrm{x}$ & $\mathrm{x}$ & $\mathrm{x}$ \\
\hline
\end{tabular}

Table 4 shows the distribution of competencies and components of the eight standards analyzed in relation to categories that emerged from the general inductive analysis. All sets of standards contain competencies or components related to at least one of the analytic categories, although the ways they present them vary significantly. The U.S. and California standards include all the analytical categories, while Texas addresses only one category of the five. The competencies and 
components of the remaining standards, including Québec's, deal with three to four analytical categories.

The first analytical category relates to the development of a climate, culture, or educational environment where human and social diversity is both recognized and respected. The approach, however, varies greatly from one competency or component to another. Most of the competencies and components in this analytic category focus solely on student recognition and inclusion. It emphasizes the establishment of a school climate or culture that respects the needs and overall wellbeing of all students, with evaluation not limited simply to academic performance. Some components sometimes extend recognition and inclusion to school staff or to the community. The "management and learning environment" competency in the California standards illustrate this perspective well, particularly in this component: "Strengthen school climate through participation, engagement, connection, and a sense of belonging among all students and staff' (Commission on Teacher Credentialing, 2014, p. 7).

In Australia and New Zealand's standards, competencies and components related to school environment are more broadly inherent to a social recognition of human diversity. In the Australia text describing the competency for engagement and working with the community, we find as many elements dealing with the school environment as we do of the recognition of the multicultural nature of the society and even regarding reconciliation with the Indigenous communities:

[Principals] create an ethos of respect taking account of the spiritual, moral, social and physical health and wellbeing of students. They promote sound lifelong learning from preschool through to adult life. They recognise the multicultural nature of Australia's people. They foster understanding and reconciliation with Indigenous cultures. They recognise and use the rich and diverse linguistic and cultural resources in the school community. They recognise and support the needs of students, families and carers from communities facing complex challenges. (Australian Institute for Teaching and School Leadership, 2014, p. 19)

The second analytical category brings together competencies and components relating to the educational dimension of the role of administrators, and more broadly to the pedagogical practices of the school staff. All of the standards contain competencies or components that affirm the educability of all students and the importance of high expectations for everyone, even of other players in the educational community, such as school staff, families as well as oneself. The analysis focuses on those which advance leadership and pedagogical practices that are not fixated on student deficits or stakeholders in the educational community, who are actualized in particular by high expectations adapted to the realities and needs of the students.

In England's standards, for example, high expectations for all students are associated with equality goals: "Demand ambitious standards for all pupils, overcoming disadvantage and advancing equality, instilling a strong sense of accountability in staff for the impact of their work on pupils' outcomes" (Department of Education, 2015, p. 6). In the California standards, a component of the competency for pedagogical leadership advocates the use of results-based management tools to respond to the needs and strengths of students: "Promote and monitor the use of state frameworks and guides that offer evidence-based instructional and support strategies to increase learning for diverse student assets and needs" (Commission on Teacher Credentialing, 2014, p. 5).

A competency in the "pedagogy" component of New Zealand's standards specifically names certain groups for whom special efforts must be made to optimize their learning. In the competency for primary school principals, the focus is on Indigenous students: "Analyse and act upon schoolwide evidence on student learning to maximise learning for all students with a particular focus on 
Māori and Pasifika students" (Ministry of Education of New Zealand, n. d., "Pedagogy"). In the standards for high school and area schools, this competency targets both Indigenous students and students with special needs: "Focus in particular on success in learning for Māori and Pasifika students, students with special education needs, and students at risk of not succeeding at school" (Ministry of Education of New Zealand, n. d., "Pedagogy").

The third analytical category includes competencies and components emphasizing the power of administrators to act to steer practices and transform structures in ways that counter the inequalities and disparities between groups of students. On the one hand, the issue of the distribution of resources appears preponderant. The standards of England, the United States, California, and Québec prescribe an equitable distribution of the different types of resources. The aims pursued by this requirement, however, differ substantially. In England's standards, the equitable distribution of resources is more a matter of good management, necessary for the viability of the school (Department for Education, 2015). In the Québec standards, one component advocates an equitable distribution of resources by respecting the rules of equity in the distribution and reallocation of means and resources while taking into account the needs of students in the school (Ministry of Education, Recreation and Sport, 2008, p. 35). In the United States and California standards, equity of resources is more explicitly part of a goal of reducing educational inequalities. Here is a sample component found in the California standards: "Provide clear rationale for decisions and distribute resources equitably to advance shared vision and goals focused on the needs of all students" (Commission on Teacher Credentialing, 2014, p. 7).

On the other hand, competencies and components identified in the standards lead administrators to identify and transform structures and practices that compromise equity, inclusion, and social justice in educational institutions. The importance of upstream analysis of available data to identify disparities between groups of students is highlighted in the Texas and California standards. A component of the Texas standards for pedagogical leadership competency, for example, emphasizes tracking data to narrow the gap between students in academic achievement: "The principal monitors multiple forms of student data to inform instructional and intervention decisions and to close the achievement gap" (Texas Education Agency, 2014, p. 1).

A component of the competency for management and learning environment of the Californian standards specifies the goals sought by this type of practice: "Consistently monitor, review and respond to attendance, discipline, and other relevant data to improve school climate and student engagement to ensure that management practices are free from bias and equitably applied to all students" (Commission on Teacher Credentialing, 2014, p. 7). On another level, a component of the equity and cultural sensitivity competency of the U.S. standard explicitly names the mechanisms and practices to be challenged, as well as the social categories involved: "Confront and alter institutional biases of student marginalization, deficit-based schooling, and low expectations associated with race, class, culture and language, gender and sexual orientation, and disability or special status" (National Policy Board for Educational Administration, 2015, p. 11).

The fourth analytical category consists a set of standards composed of competencies and components that prescribe the commitment of families and communities as well as the mobilization of their resources to meet the needs of students from marginalized or under-represented groups in the school structure and culture. The California standards are the most explicit for this analytic category. In relation to the goals of equity, inclusion, and social justice, one component notably targets underrepresented communities: "Leaders meaningfully involve all parents and families, including underrepresented communities, in student learning and support programs" (Commission on Teacher Credentialing, 2014, p. 7). One component of competency for external context and policies especially targets students learning the language of instruction as well as students with 
special needs: "Welcome and facilitate conversations with the local community about how to improve learning and achievement for all students, including English Learners, and students needing additional support" (Commission on Teacher Credentialing, 2014, p. 10). In the New Zealand standards, the competencies related to the fourth category relate more specifically to Indigenous communities. One competency emphasizes relations with the nation's Indigenous communities: "Actively foster positive relationships with the school's community and local iwi" (Ministry of Education of New Zealand, n. d., "Partnerships and Networks").

Finally, the fifth analytical category highlights competencies and components that focus on professional standards and professional development from an ethical perspective. Most state the broader principles and values that should guide administrator actions. This is particularly the case in the Québec standards, where it is argued that administrators must interact with every person with respect, justice and equity (Ministry of Education, Recreation and Sports, 2008, p. 40). The components of the "Ethics and Integrity" competency of the California standards clarify the role and action of administrators in order to actualize such principles and values. For example, a component calls on them to "Examine personal assumptions, values, and beliefs to address students' various academic, linguistic, cultural, social-emotional, physical, and economic assets and needs and promote equitable practices and access appropriate resources" (Commission on Teacher Credentialing, 2014, p. 9), while another urges them to "use a variety of strategies to lead others in safely examining personal assumptions and respectfully challenge beliefs that negatively affect improving teaching and learning for all students" (Commission on Teacher Credentialing, 2014, p. 9). Another component invites administrators to "commit to making difficult decisions in service of equitable outcomes for students, staff and the school community" (Commission on Teacher Credentialing, 2014, p. 9). These components engage the critical thinking of the administrators in order to question the frames of reference (assumptions, values, and beliefs) that can compromise the key values of the professional standards, but also to help them make the "difficult decisions" when it comes time to ensure equity.

Other competencies and components also deal with professional development. The school administrator is responsible for her/his own professional development, but must also support the members of the school team in this process. A component of the competency for instructional leadership of the California standards, for example, calls on administrators to "Promote professional learning plans that focus on real situations and specific needs related to increasing the learning and well-being of all staff and students" (Commission on Teacher Credentialing, 2014, p. 5). Among the New Zealand standards, a competency intended more specifically for primary school principals addresses the professional development of staff with regard to teacher-student relations, but in particular with the Māori students: "Ensure staff members engage in professional learning to establish and sustain effective teacher/learner relationships with all students, with a particular focus on Māori students" (Ministry of Education of New Zealand, n. d, "Pedagogy").

\section{Discussion}

The eight competency standards analyzed are from jurisdictions with many similarities, both demographic and political. These countries, states, and provinces have, with the exception of England, been based on territories occupied for a long time by Indigenous peoples before colonization. Their populations were thereafter transformed by the arrival of immigrants and structures were put in place to ensure their selection and integration. Their political systems are of the liberal-democratic type, supporting the protection of individual rights and freedoms. Despite these similar socio-political contexts, the analysis reveals a varied response to the issues under study, 
whether in the level of social categories taken into account, the proposed vision of the school leaders, or the competencies and components reflecting educational and societal goals of equity, inclusion, and social justice. The standards can be divided into three groups.

The standards of Australia, California, and the United States form the first group. The results of the analysis showed that only these standards propose a vision of a school leader fully pursuing goals of equity, inclusion, and social justice in education. More than the others, a critical perspective of the diversity of individuals' experiences and identities emerges from the competencies listed in these three sets of standards. Rather than explaining gaps in educational success through student deficits, principals are encouraged to act to counter structures and practices that compromise student success and social recognition (Dei et al., 2000; Shields, 2012). The issues of inclusion, equity, and social justice are presented as being primarily the responsibility of the educational institutions and stakeholders. Australia's standards are also distinct, since they highlight that society's commitment to inclusiveness and social recognition of diversity as constitutive, particularly in relation to Indigenous communities This dimension is particularly evident in the vision of the school leader.

The standards for British Columbia and New Zealand form a second group. These standards explicitly name certain social categories and include competencies and components that can contribute to taking into account social diversity in a perspective of equity, inclusion, and social justice. However, they do not propose a corresponding vision of the school leader. The analysis made it possible to identify within the two sets of standards the consideration of the differentiated needs of students in a perspective of educational success, as well as a better recognition of the diversity of their experiences and identities. These statements are not, however, as central here as they are in the Australia, California, and U.S. standards. They are scattered in different places in the standards and are moreover situated at an "individual-relational" level of reflection and action rather than at a "structural-systemic" level. In other words, few components propose the analysis of the (re)production of inequalities in the functioning of the educational institution (Dhume-Sonzogni, 2014). The reference standards instead encourage the transformation of individual practices, even of people themselves, which is reminiscent of the premises of a deficit-centered approach (Ainscow \& Miles, 2008). Finally, it should be noted that the New Zealand standard is the only one in this second set to take into account Indigenous issues and the educational reality of these communities.

The competency standards in England, Texas, and Québec can be classified in a third group. No social category is named in any of these three standards. Rather, generic statements refer to students' differentiated needs or success. The vision of the engaged school leader in these standards also does not meet the goals of a perspective of equity, inclusion, and social justice. It is only possible to identify within these three sets of standards a few competencies and components that largely aim to meet the differentiated needs of students. Like the standards themselves, these aims are expressed in a language of efficiency and performance. In the Québec standards, for example, the terms efficiency, accountability, data monitoring, and results are used repeatedly. The goals pursued by this quest for performance remain unclear, however, and are not explicitly linked to the goal of equity, inclusion, and social justice. The influence of New Public Management (NPM) is evident in these three standards. These management and governance models, derived from the private sector and transplanted into public institutions, have been implemented in all of the educational systems studied in different ways (Maroy, 2013). The influence of the NPM can be explained by the standards chosen, all of which come from Anglo-occidental countries within the OECD. The sets of standards in which managerial language and the new public management style are the most significant are also those in which the recognition of human and social diversity in the school environment is the weakest. At first glance, there is a tension between the managerial approach, 
oriented toward measurable results and the control of costs, and the objectives of equity, inclusion, and social justice (Bauer \& Akkari, 2015).

\section{Conclusion}

The consideration of human and social diversity from the perspective of equity, inclusion, and social justice varies from one frame of reference to another. The comparative analysis conducted offers several models of the prescriptions for school administrators, revealing in some cases the pervasiveness of an approach oriented towards performance objectives and measurable results. The standards of the Anglo-occidental countries analyzed, which are infused with neoliberal ideology (Magno, 2013), can partly explain these results. The standards guiding the training and work of Québec's school administrators reflect the influence of results-based management, which was introduced in Québec public institutions in 2000 (Brassard, Lusignan, \& Pelletier, 2013). The vision emanating from this document gives little importance to the right to education for all, nor is the principle of equality of opportunity at the heart of the mission of Québec schools, as set out in the Education Act (2019). This mission is substituted in the Québec standards by a decentralized vision, calling on principals to adapt to the specific context of each school and the students attending it. From a professional development perspective, the Québec standards focus on the responsibility of school principals to manage change in education. Despite the limitations inherent in the choice of standards, comparative analysis allows us to see, on the one hand, some cultural and contextual differences (Dimmock \& Walker, 1998) in the way countries, provinces or states face the problems of equity, inclusion and social justice. On the other hand, the historical and social specificities of Québec - a fragile francophone majority in Canada and North America - do not appear to emerge from the Québec standards. The analysis shows how ideology and the generalized economic values in the context of globalization (Carney, 2009; Magno, 2013) may interfere with the objectives of equity, inclusion and social justice (Bauer \& Akkari, 2015; Ward et al., 2014).

Although competencies are assigned to individuals and are their responsibility, they also assume a shared responsibility between the person, the context - including other people - and the organizational set-up (Legendre, 2008). In other words, the development of professional competencies requires an organizational context conducive to them, that is, one that values individual responsibility, risk-taking, and autonomy, that encourages the sharing of complementary expertise, and that makes resources available. While the proposed model directly engages the principals of educational institutions in Québec and the school communities working with them, the Group also made recommendations involving decision-makers with responsibilities for training, coaching and supervising, and evaluating administrator practices and, above all, the Québec Ministry of Education. By supporting the principles of equity, inclusion, and social justice at all levels of the education system with concrete actions, administrators will feel better supported in the development of these competencies (Norberg, 2017; Young et al., 2010) and in the guiding of their staff and communities in this process.

The competencies are thus not merely individual capacities. They have a collective dimension attached to the context, but also to a purpose and an end. No competency exists in the abstract, having meaning only in relation to the action, the aim pursued by this action and the context in which it fits (Legendre, 2008, p. 34). The action, purpose, and context always vary, but some ends transcend them. The comparative analysis of the standards has in short helped to develop a model of competencies for principals explicitly pursuing the goals of equity, inclusion, and social justice, worded as follows: Act as a leader to establish a fair, just and inclusive environment in the establishment of the identities and individual and collective experiences of individuals, and to 
promote action to counter inequalities, exclusions and discriminations experienced by members of minority groups (Larochelle-Audet et al., 2018, p. 72). ${ }^{8}$

\section{References}

Ahmed, S. (2009). Embodying diversity: Problems and paradoxes for Black feminists. Race Ethnicity and Education, 12(1), 41-52. http://dx.doi.org/10.1080/13613320802650931

Ainscow, M., \& Miles, S. (2008). Vers une éducation pour l'inclusion pour tous: prochaine étape? Perspectives, 18(1), 17-44.

Apple, M. W., \& Beane, J. A. (2007). Democratic schools (2 ${ }^{\text {nd }}$ ed.). Alexandria, VA: Association for Supervision and Curriculum Development.

Archambault, J., \& Garon, R. (2013). How principals exercise transformative leadership in urban schools in disadvantaged areas in Montréal, Canada. International Studies in Educational Administration, 41(2), 49-66.

Archambault, J., \& Richer, C. (2014). Leadership for social justice throughout fifteen years of intervention in a disadvantaged and multicultural Canadian urban area: The supporting Montréal schools program. In I. Bogotch, \& C. M. Shields (Eds.), International handbook of educational leadership and social (in)justice (pp. 1023-1045). Dordrecht, the Netherlands: Springer.

AuCoin, A., \& Vienneau, R. (2015). L'inclusion scolaire et la dénormalisation: Proposition d'un nouveau paradigme. In N. Rousseau (Ed.), La pédagogie de l'inclusion scolaire (3 ${ }^{\text {rd }}$ ed., pp. 65-87). Québec City, QC: Presses de l'Université du Québec.

Australian Institute for Teaching and School Leadership. (2014). Australian Professional Standard for Principals and the Leadership Profiles. Melbourne, Australia: Standing Council on School Education and Early Childhood (SCSEEC) [now the Education Council].

Bauer, S., \& Akkari, A. (2015). La gestion de la diversité culturelle par les chefs d'etablissement: Revue de la littérature. Revista Educação e Políticas em Debate, 4(1), 150-172.

Bernatchez, J. (2011). La formation des directions d'établissement scolaire au Québec: Apprendre à développer un savoir-agir complexe. Télescope, 17(3), 158-175.

Blais, M., \& Martineau, S. (2006). L'analyse inductive générale: Description d'une démarche visant à donner un sens à des données brutes. Recherches qualitatives, 26(2), 1-18.

Borri-Anadon, C. (2014). Pratiques évaluatives des orthophonistes scolaires à l'égard des élèves issus de minorités culturelles: Une recherche interprétative-critique. (Doctoral thesis). Université du Québec à Montréal. Retrieved from http://www.archipel.uqam.ca/6351/

Borri-Anadon, C. (2016). Les enjeux de l'évaluation des besoins des élèves en contexte de diversité. Dans M. Potvin, M.-O. Magnan, \& J. Larochelle-Audet (Ed.), La diversité ethnoculturelle, religieuse et linguistique en éducation au Québec. Théorie et pratique (pp. 215-224). Montréal, QC: Fides Education.

Borri-Anadon, C., Potvin, M., \& Larochelle-Audet, J. (2015). La pédagogie de l'inclusion, une pédagogie de la diversité. Dans N. Rousseau (Ed.), La pédagogie de l'inclusion scolaire (3 ${ }^{\text {rd }}$ ed., pp. 49-63). Québec City, QC: Presses de l’Université du Québec.

Borri-Anadon, C., Potvin, M., Longpré, T., Pereira Braga, L., \& Orange, V. (2018). La formation du personnel scolaire sur la diversité ethnoculturelle, religieuse et linguistique dans les universités québécoises: Portrait quantitatif de l'offre de cours de deuxième cycle en

\footnotetext{
${ }^{8}$ The developed competency model can be found in the French-language report of the Working Group on Competencies and Training for Administrators in Equity and Diversity, available online at http://ofde.ca/wp-content/uploads/2018/03/Groupe-directions_rapport_avril2018_vf.pdf.
} 
éducation. Retrieved from http://ofde.ca/wp-content/uploads/2018/03/Portrait-2e-cycleVF v5.pdf

Bouchamma, Y., \& Tardif, C. (2011). Les pratiques des directions d'école en contexte de diversité ethnoculturelle. Montréal, QC: Presses de l’Université de Montréal.

Brassard, A., Lusignan, J., \& Pelletier, G. (2013). La gestion axée sur les résultats dans le système éducatif du Québec: Du discours à la pratique. In C. Maroy (Ed.), L'école à l'épreuve de la performance: Les politiques de régulation par les résultats (pp. 13-31). Bruxelles, Belgique: De Boeck.

British Columbia Principals' \& Vice-Principals' Association. (2015). Leadership standards for principals and vice-Principals in British Columbia. Vancouver, BC: Author.

Carney, S. (2009). Negotiating policy in an age of globalization: Exploring educational "Policyscapes" in Denmark, Nepal, and China. Comparative Education Review, 53(1), 63-88. http://dx.doi.org/10.1086/593152

Charter of Human Rights and Freedoms, CQLR, c. C-12, (2016). Retrieved from https://www.canlii.org/en/qc/laws/stat/cqlr-c-c-12/latest/cqlr-c-c-12.html

Collins, P. H., \& Bilge, S. (2016). Intersectionality. Cambridge, UK: Polity Press.

Commission on Teacher Credentialing. (2014). California Professional Standards for Education Leaders (CPSEL). Sacramento, CA: Author.

Commission of Human Rights and Youth Rights. (2009). Mémoire présenté au Conseil supérieur de l'éducation dans le cadre de la consultation sur l'accès à l'éducation et l'accès à la réussite éducative dans une perspective d'éducation pour l'inclusion. Québec City, QC: Author.

Commission of Human Rights and Youth Rights. (2011). Racial profiling and systemic discrimination of racialized youth. Report of the consultation on racial profiling and its consequences. Québec City, QC: Author.

Conseil supérieur de l'éducation. (2010). Balancing equity and performance in education: A challenge for society. Report on the state and needs of education 2008-2010. Québec City, QC: Author.

Conseil supérieur de l'éducation. (2016). Steering the course back to equity in education. Report on the state and needs of education 2014-2016. Québec City, QC: Author.

Cooper, C. W. (2009). Performing cultural work in demographically changing schools: Implications for expanding transformative leadership frameworks. Educational Administration Quarterly, 45(5), 694-724.

Crenshaw, K., Ocen, P., \& Nanda, J. (2015). Black girls matter: Pushed out, overpoliced, and underprotected. New York, NY: African American Policy Forum and Center for Intersectionality and Social Policy Studies.

D’Arrisso, D. (2013). Pressions et stratégies dans la formation professionnelle universitaire: Le cas de la formation des directions d'établissement scolaire du Québec (1988-1989 à 2008-2009). (Doctoral thesis).

Université de Montréal. Retrieved from http://hdl.handle.net/1866/10219

Dei, G. J., Karumanchery, L. L., James-Wilson, S., James, I. M., Zine, J., \& Rinaldi, C. (2000). Removing the margins: The challenges \& possibilities of inclusive schooling. Edmonton, AB: Canadian Scholars' Press.

Delphy, C. (2013). L'ennemi principal. 2. Penser le genre (3 ${ }^{\text {rd }}$ ed.). Paris, France: Syllepse.

DeMatthews, D., \& Mawhinney, H. (2014). Social justice leadership and inclusion: Exploring challenges in an urban district struggling to address inequities. Educational Administration Quarterly, 50(5), 844-881.

Department for Education. (2015). National standards of excellence for headteachers. Departmental advice for beadteachers, governing boards and aspiring headteachers. London, United Kingdom: Author.

Dhume-Sonzogni, F. (2014). Entre l'école et l'entreprise: La discrimination en stage. Une sociologie publique de l'ethnicisation des frontières scolaires. Aix-en-Provence, France: Presses universitaires de Provence. 
Dimmock, C. \& Walker, A. (1998). Towards comparative educational administration: building the case for a cross-cultural school-based approach. Journal of Educational Administration, 36(4), 379-401. http://dx.doi.org/10.1108/09578239810211554

Dubet, F., Duru-Bellat, M., \& Vérétout, A. (2010). Les inégalités entre l'amont et l'aval. Organisation scolaire et emprise des diplômes. Sociologie, 1(2), 177-197.

Education Act, CQLR, c. I-13.3. (2019). Retrieved from https://www.canlii.org/en/qc/laws/stat/cqlr-c-i-13.3/147459/cqlr-c-i-13.3.html

European Group of Research on Equity of the Educational Systems. (2005). Equity in European Educational Systems. A set of indicators ( ${ }^{\text {nd }}$ ed.). Project supported by the European Commission. Directorate General of Education and Culture. Projet Socrates SO2-61OBGE. Liège, Belgium: University of Liège.

Fraser, N. (1998). Penser la justice sociale: Entre redistribution et revendications identitaires. Politique et Sociétés, 17(3), 9-36.

Gélinas Proulx, A., IsaBelle, C., \& Meunier, H. (2014). Compétence des nouvelles directions d'école de langue française au Canada pour la gestion inclusive de la diversité ethnoculturelle, linguistique et religieuse. Alterstice, 4(1), 73-88.

Gélinas Proulx, A., \& Shields, C. M. (2016). Le leadership transformatif: Maintenir la langue francaise vivante au Canada . Canadian Journal of Education / Revue canadienne de l'éducation, $39(1), 1-24$.

Guillaumin, C. (2002). L’idéologie raciste. Genèse et langage actuel. Paris, France: Gallimard. (Original work published in 1972)

Hunt, J. G. (2005). Explosion of the leadership field and LQ's changing of the editorial guard. The Leadership Quarterly, 16, 1-8. http://dx.doi.org/10.1016/j.leaqua.2004.10.003

IsaBelle, C., Meunier, H., \& Gélinas Proulx, A. (2016). Contextes de formation des nouvelles directions d'école au Canada. McGill Journal of Education, 51(2), 877-898. http://dx.doi.org/ 10.7202/1038607ar

James, C., \& Turner, T. (2017). Toward race equity in education: The schooling of Black students in the greater Toronto area. Toronto, ON: York University.

Juteau, D. (Ed.) (2003). La différenciation sociale: Modèles et processus. Montréal, QC: Presses de l'Université de Montréal.

Kamanzi, P. C., \& Pilote, A. (2016). Parcours scolaires et reproduction sociale au Québec. In J. Masdonati, M. Bangali, \& L. Cournoyer (Eds.), Éducation et vie au travail, Tome 1: Perspectives contemporaines sur l'orientation et les parcours des jeunes (pp. 9-45). Québec City, QC: Presses de l'Université Laval.

Khalifa, M. A., Gooden, M. A., \& Davis, J. E. (2016). Culturally responsive school leadership. Review of Educational Research, 86(4), 1272-1311.

Larochelle-Audet, J. (2019). Organisation et re-production des rapports de domination dans les distributions dissymétriques du travail enseignant: Une enquête du point de vue d'enseignant -es de groupes racisés. (Unpublished doctoral thesis). Université de Montréal.

Larochelle-Audet, J., Magnan, M.-O., Potvin, M., Doré, E., Amboulé Abath, A., Gélinas Proulx, A., Thibodeau, S. (2018). Les compétences des directions en matière d'équité et de diversité: Pistes pour les cadres de référence et la formation. Rapport du Groupe de travail sur les compétences et la formation des directions en matière d'équité et de diversité, Observatoire sur la formation à la diversité et l'équité. Retrieved from http://ofde.ca/wpcontent/uploads/2018/03/Groupe-directions rapport fev2018.compressed.pdf

Legendre, M.-F. (2008). La notion de compétence au coeur des réformes curriculaires: Effet de mode ou moteur de changement en profondeur? In F. Audigier \& N. Tutiaux-Guillon 
(Eds.), Compétences et contenus: Les curriculums en questions (pp. 27-50). Brussels, Belgium: De Boeck Supérieur.

Magnan, M.-O., Gosselin-Gagné, J., Charette, J., \& Larochelle-Audet, J. (2018). Gestionnaires et diversité ethnoculturelle en milieu scolaire: Une recherche-action/formation en contexte montréalais. Education et francophonie, XLVI(2), 125-145. Retrieved from https://www.acelf.ca/c/revue/pdf/EF-46-2-125 MAGNAN 46-2.pdf

Magnan, M.-O., \& Vidal, M. (2015). Le tri social et ses conséquences sur le parcours scolaire des élèves. In S. Demers, D. Lefrançois, \& M.-A. Éthier (Eds.), Les fondements de l'éducation : perspectives critiques (pp. 209-261). Montréal, QC: Éditions MultiMondes.

Magno, C. S. (2013). Comparative perspectives on international school leadership: Policy, preparation, and practice. New York, NY: Routledge.

Marcotte-Fournier, A.-G., Bourdon, S., Lessard, A., \& Dionne, P. (2016). Une analyse des effets de composition du groupe-classe au Québec: Influence de la ségrégation scolaire et des projets pédagogiques. Education et Sociétés, 2(38), 139-155.

Maroy, C. (2013). Politiques et outils de "l'école de la performance": Accountability, régulation par les résultats et pilote. In C. Maroy (Ed.), L'école à l'éprewve de la performance: Les politiques de régulation par les résultats (pp. 13-31). Brussels, Belgium: De Boeck.

Maroy, C., \& Kamanzi, P. C. (2017). Marché scolaire, stratification des établissements et inégalités d'accès à l'université au Québec. Recherches sociographiques, 58(3), 581-602.

McShane, S. L., \& Benabou, C. (2008). Comportement organisationnel: Comportements humains et organisations dans un environnement complexe. Montréal, QC: Chenelière McGraw-Hill.

Ministry of Education. (1998). A school for the future: Policy statement on intercultural education and cultural integration. Québec City, QC: Author.

Ministry of Education. (2014). Equity and inclusive education in Ontario schools: Guidelines for policy development and implementation. Toronto, ON: Queen's Printer for Ontario.

Ministry of Education and Higher Education. (2017). Policy on educational success: A love of learning, a chance to succeed. Québec City, QC: Author.

Ministry of Education of New Zealand. (n. d.). Professional standards for 1) primary school principals 2) secondary school principals 3) area school principals. Extract from the collective agreements. Auckland, New Zealand: Author.

Ministry of Education, Recreation and Sports. (2008). Training in the administration of an educational institution: Orientations and professional competencies. Québec City, QC: Author.

Ministry of Immigration and Cultural Communities. (2008). Diversity: An added value: Government policy to promote participation of all in Québec's development. Québec City, QC: Author.

National Policy Board for Educational Administration. (2015). Professional standards for educational leaders [formerly known as ISLLC Standards]. Reston, VA: Author.

Norberg, K. (2017). Educational leadership and im/migration: Preparation, practice and policy The Swedish case. International Journal of Educational Management, 31(5), 633-645.

Ouellet, F. (2010). La prise en compte de la diversité en milieu scolaire. In P. Toussaint (Ed.), La diversité etbnoculturelle en éducation. Enjeux et défis pour l'école québécoise (pp. 275-316). Québec City, QC: Presses de l'Université du Québec.

Pereira Braga, L., \&Magnan, M.-O. (2015). Les pratiques des directions en milieu scolaire pluriethnique: Un projet pilote sur l'île de Montréal. [Rapport de recherche]. Centre d'intervention pédagogique en contexte de diversité, Commission scolaire Marguerite-Bourgeoys. Retrieved from https://cipcd.ca/wp-content/uploads/2016/02/Rapport-BRAGA-MAGNAN-2015.pdf 
Pont, B. (2013). Learning standards, teaching standards and standards for school principals: A comparative study. (Report no. EDU/WKP(2013)14). Santiago, Chile: Centre of Study for Policies and Practices in Education (CEPPE).

Potvin, M. (2013). L'éducation inclusive et antidiscriminatoire : fondements et développement d'institutions inclusives en contexte de diversité. In M. McAndrew, M. Potvin, \& C. BorriAnadon (Eds.), Le développement d'institutions inclusives en contexte de diversité. Recherche, formation, partenariat (pp. 9-26). Montréal, QC: Presses de l'Université du Québec.

Potvin, M., Borri-Anadon, C., Larochelle-Audet, J., Armand, F., Beck, I. A., Cividini, M., Chastenay, M.-H. (2015). Rapport sur la prise en compte de la diversité ethnoculturelle, religieuse et linguistique dans les orientations et compétences professionnelles en formation à l'enseignement. Rapport du Groupe de travail interuniversitaire sur les compétences interculturelles et inclusives en éducation, Observatoire sur la formation à la diversité et l'équité. Retrieved from http://collections.banq.qc.ca/ark:/52327/bs2482627.

Potvin, M., \& Pilote, A. (2016). Les rapports ethniques et les processus d'exclusion. In M. Potvin, M.-O. Magnan, \& J. Larochelle-Audet (Eds.), La diversité ethnoculturelle, religieuse et linguistique en éducation au Québec. Théorie et pratique (pp. 79-98). Montréal, QC: Fides Education.

Prud'homme, L. (2007). La différenciation pédagogique: Analyse du sens construit par des enseignantes et un chercheur-formateur dans un contexte de recherche action-formation. (Doctoral thesis). Université du Québec en Outaouais. Retrieved from https://archipel.uqam.ca/745/1/D1599.pdf

Ricci, S. (2015). Quand le sourire de la diversité cache les rapports de domination. In N. Hamrouni \& C. Maillé (Eds.), Le sujet du féminisme est-il blanc? Femmes racisées et recherche féministe (pp. 175193). Montréal, QC: Remue-ménage.

Riehl, C. J. (2000). The principal's role in creating inclusive schools for diverse students: A review of normative, empirical, and critical literature on the practice of educational administration. Review of Educational Research, 70(1), 55-81.

Ryan, J. (2012). Struggling for inclusion: Educational leadership in a neoliberal world. Charlotte, NC: IAP.

Ryan, J., Pollock, K., \& Antonelli, F. (2009). Teacher diversity in Canada: Leaky pipelines, bottlenecks, and glass ceilings. Canadian Journal of Education/Revue canadienne de l'éducation, 32(3), 591-617.

Shields, C. M. (2012). Transformative leadership in education: Equitable change in an uncertain and complex world. New York, NY: Routledge.

Sleeter, C. E., \& Grant, C. A. (2009). Making choices for multicultural education: Five approaches to race, class and gender $\left(6^{\text {th }}\right.$ ed.). Hoboken, NJ: John Wiley \& Sons.

Texas Education Agency. (2014). Texas Education Code, \21.3541, Chapter 149. Commissioner's Rules Concerning Educator Standards. Subchapter BB. Administrator Standards. \149.2001. Principal Standards. Adopted to be effective June 8, 2014, 39 TexReg 4245. Retrieved from http://ritter.tea.state.tx.us/rules/tac/chapter149/ch149bb.html

Theoharis, G., \& Causton-Theoharis, J. N. (2008). Oppressors or emancipators: Critical dispositions for preparing inclusive school leaders. Equity \& Excellence in Education, 41(2), 230-246. http://dx.doi.org/10.1080/10665680801973714

Thibodeau, S., Gélinas Proulx, A., St-Vincent, L.-A., Leclerc, M., Labelle, J., \& Ramel, S. (2016). La direction d'école: Un acteur crucial pour l'inclusion scolaire. Dans L. Prud'homme, H. Duchesne, P. Bonvin, \& R. Vienneau (Eds.), L'inclusion scolaire: Ses fondements, ses acteurs et ses pratiques (pp. 57-69). Brussels, Belgium: De Boeck Supérieur.

Tuters, S., \& Portelli, J. (2017). Ontario school principals and diversity: Are they prepared to lead to equity? International Journal of Educational Management, 31(5), 598-611. 
Ward, S., Bagley, C., Woods, P., Lumby, J., Hamilton, T., \& Roberts, A. (2014). School leadership and equity: A critical review of the literature. International Journal of Inclusive Education, 19(4), 333-346. http://dx.doi.org/10.1080/13603116.2014.930520

Wilson, C. M. (2014). Cultural work and demographic changing schools: New opportunities for transformative leadership. In C. M. Wilson \& S. Douglass Horsford (Eds.), Advancing equity and achievement in America's diverse schools (pp. 57-76). New York, NY: Routledge.

Young, B. L., Madsen, J., \& Young, M. A. (2010). Implementing diversity plans: Principals' perception of their ability to address diversity in their schools. NASSP Bulletin, 94(2), 135157.

\section{About the Authors}

Julie Larochelle-Audet

Université de Montréal

julie.larochelle-audet@umontreal.ca

Julie Larochelle-Audet is an assistant professor of educational administration at the Faculty of Education of the Universite de Montréal and a member of the Groupe de recherche interrégional sur l'organisation du travail des directions d'établissement d'enseignement. Its most recent projects address the issues of work, training and competencies development of school principals from the perspective of equity, inclusion, and social justice.

\section{Marie-Odile Magnan}

Université de Montréal

marie-odile.magnan@,umontreal.ca

Marie-Odile Magnan is an associate professor of sociology of education at the Faculty of Education of the Université de Montréal and a member of the Centre de recherche interuniversitaire sur la formation et la profession enseignante. Its projects involve the implementation of the principles of equity and inclusion in institutional practices and on the academic experiences and identity of young people from minoritized groups.

\section{Maryse Potvin}

Université du Québec à Montréal

potvin.maryse@,uqam.ca

Maryse Potvin is a full professor of sociology of education at the Université du Québec à Montréal and head of the Observatoire sur la formation à la diversité et l'equité (OFDE). For 25 years, her work and publications have focused on racism and ethnic relations in Québec and Canada, especially regarding public structures, social and mediatized discourse, and issues of identity, equity, education and training (in anti-racism, inclusiveness, interculturality, human rights).

\section{Emmanuelle Doré}

Université du Québec à Montréal

dore.emmanuelle@,uqam.ca

Emmanuelle Doré is a doctoral candidate in educational administration at the Université de Montréal and a visiting professor in the Department of Didactics of the Faculty of Education at the Université du Québec à Montréal. Her research focuses on leadership, social justice, the concept of "at-risk student," relationships between social actors in the public education system, and discourse as a social practice. 


\title{
About the Guest Editors
}

\author{
Augusto Riveros \\ Western University \\ gus.riveros@uwo.ca \\ ORCID: http://orcid.org/0000-0002-9942-6380
}

Augusto Riveros is associate professor in critical policy equity and leadership studies in the Faculty of Education at Western University in Ontario. Canada. His areas of interest include methods and theory in educational administration and leadership, policy analysis and education reform. His work has been published in numerous international journals and edited books. Dr. Riveros' research has been supported by the Social Sciences and Humanities Research Council of Canada (SSHRC).

\section{Wei Wei}

Western University

wwei32@uwo.ca

ORCID: http://orcid.org/0000-0002-0090-5614

Wei Wei is a Ph.D. Candidate in critical policy, equity, and leadership studies in the Faculty of Education at Western University in Ontario Canada. Her research interests include educational leadership, policy analysis, and comparative and international education.

\section{Special Issue \\ Standards and Competency Frameworks for School Administrators: Global, Comparative and Critical Perspectives \\ education policy analysis archives}

Volume 27 Number $112 \quad$ September 23, 2019

ISSN 1068-2341

\section{(9) (1) (-)}

Readers are free to copy, display, distribute, and adapt this article, as long as the work is attributed to the author(s) and Education Policy Analysis Archives, the changes are identified, and the same license applies to the derivative work. More details of this Creative Commons license are available at https://creativecommons.org/licenses/by-sa/2.0/. EPAA is published by the Mary Lou Fulton Institute and Graduate School of Education at Arizona State University Articles are indexed in CIRC (Clasificación Integrada de Revistas Científicas, Spain), DIALNET (Spain), Directory of Open Access Journals, EBSCO Education Research Complete, ERIC, Education Full Text (H.W. Wilson), QUALIS A1 (Brazil), SCImago Journal Rank, SCOPUS, SOCOLAR (China).

Please send errata notes to Audrey Amrein-Beardsley at audrey.beardsley@asu.edu

Join EPAA's Facebook community at https://www.facebook.com/EPAAAAPE and Twitter feed@epaa_aape. 


\section{education policy analysis archives editorial board}

Lead Editor: Audrey Amrein-Beardsley (Arizona State University)

Editor Consultor: Gustavo E. Fischman (Arizona State University)

Associate Editors: Melanie Bertrand, David Carlson, Lauren Harris, Eugene Judson, Mirka Koro-Ljungberg, Daniel Liou, Scott Marley, Molly Ott, Iveta Silova (Arizona State University)

Cristina Alfaro

San Diego State University

Gary Anderson

New York University

Michael W. Apple

University of Wisconsin, Madison

\section{Jeff Bale}

University of Toronto, Canada

Aaron Bevanot SUNY Albany

David C. Berliner

Arizona State University

Henry Braun Boston College

Casey Cobb
University of Connecticut
Arnold Danzig
San Jose State University
Linda Darling-Hammond
Stanford University
Elizabeth H. DeBray
University of Georgia
David E. DeMatthews
University of Texas at Austin
Chad d'Entremont Rennie Center
for Education Research \& Policy
John Diamond
University of Wisconsin, Madison
Matthew Di Carlo
Albert Shanker Institute
Sherman Dorn
Arizona State University
Michael J. Dumas
University of California, Berkeley
Kathy Escamilla
University ofColorado, Boulder
Yariv Feniger Ben-Gurion
University of the Negev
Melissa Lynn Freeman
Adams State College
Rachael Gabriel
University of Connecticut

Amy Garrett Dikkers University of North Carolina, Wilmington Gene V Glass

Arizona State University

Ronald Glass University of

California, Santa Cruz

Jacob P. K. Gross

University of Louisville

Eric M. Haas WestEd

Julian Vasquez Heilig California State University, Sacramento Kimberly Kappler Hewitt University of North Carolina Greensboro

Aimee Howley Ohio University

Steve Klees University of Maryland Jaekyung Lee SUNY Buffalo Jessica Nina Lester Indiana University

Amanda E. Lewis University of Illinois, Chicago

Chad R. Lochmiller Indiana

University

Christopher Lubienski Indiana

University

Sarah Lubienski Indiana University

William J. Mathis

University of Colorado, Boulder

Michele S. Moses

University of Colorado, Boulder

Julianne Moss

Deakin University, Australia

Sharon Nichols

University of Texas, San Antonio

Eric Parsons

University of Missouri-Columbia

Amanda U. Potterton

University of Kentucky

Susan L. Robertson

Bristol University
Gloria M. Rodriguez

University of California, Davis

R. Anthony Rolle

University of Houston

A. G. Rud

Washington State University

Patricia Sánchez University of

University of Texas, San Antonio

Janelle Scott University of

California, Berkeley

Jack Schneider University of

Massachusetts Lowell

Noah Sobe Loyola University

Nelly P. Stromquist

University of Maryland

Benjamin Superfine

University of Illinois, Chicago

Adai Tefera

Virginia Commonwealth University

A. Chris Torres

Michigan State University

Tina Trujillo

University of California, Berkeley

Federico R. Waitoller

University of Illinois, Chicago

Larisa Warhol

University of Connecticut

John Weathers University of

Colorado, Colorado Springs

Kevin Welner

University of Colorado, Boulder

Terrence G. Wiley

Center for Applied Linguistics

John Willinsky

Stanford University

Jennifer R. Wolgemuth

University of South Florida

Kyo Yamashiro

Claremont Graduate University

Miri Yemini

Tel Aviv University, Israel 


\section{archivos analíticos de políticas educativas consejo editorial}

Editor Consultor: Gustavo E. Fischman (Arizona State University)

Felicitas Acosta (Universidad Nacional de General Sarmiento, Argentina), Armando Alcántara Santuario (Universidad Nacional Autónoma de México), Ignacio Barrenechea, Jason Beech (Universidad de San Andrés), Angelica Buendia, (Metropolitan Autonomous University), Alejandra Falabella (Universidad Alberto Hurtado, Chile), Veronica Gottau (Universidad Torcuato Di Tella), Antonio Luzon, (Universidad de Granada), José Luis Ramírez, (Universidad de Sonora), Paula Razquin, Axel Rivas (Universidad de San Andrés), Maria Alejandra Tejada-Gómez (Pontificia Universidad Javeriana, Colombia)

Claudio Almonacid

Universidad Metropolitana de Ciencias de la Educación, Chile

Miguel Ángel Arias Ortega

Universidad Autónoma de la

Ciudad de México

Xavier Besalú Costa

Universitat de Girona, España

Xavier Bonal Sarro Universidad

Autónoma de Barcelona, España

Antonio Bolívar Boitia

Universidad de Granada, España

José Joaquín Brunner Universidad

Diego Portales, Chile

Damián Canales Sánchez

Instituto Nacional para la

Evaluación de la Educación,

México

Gabriela de la Cruz Flores

Universidad Nacional Autónoma de

México

Marco Antonio Delgado Fuentes

Universidad Iberoamericana,

México

Inés Dussel, DIE-CINVESTAV, México

Pedro Flores Crespo Universidad Iberoamericana, México
Ana María García de Fanelli

Centro de Estudios de Estado y

Sociedad (CEDES) CONICET,

Argentina

Juan Carlos González Faraco

Universidad de Huelva, España

María Clemente Linuesa

Universidad de Salamanca, España

Jaume Martínez Bonafé

Universitat de València, España

Alejandro Márquez Jiménez

Instituto de Investigaciones sobre la

Universidad y la Educación,

UNAM, México

María Guadalupe Olivier Tellez,

Universidad Pedagógica Nacional,

México

Miguel Pereyra Universidad de

Granada, España

Mónica Pini Universidad Nacional

de San Martín, Argentina

Omar Orlando Pulido Chaves

Instituto para la Investigación

Educativa y el Desarrollo

Pedagógico (IDEP)

José Ignacio Rivas Flores

Universidad de Málaga, España
Miriam Rodríguez Vargas

Universidad Autónoma de

Tamaulipas, México

José Gregorio Rodríguez

Universidad Nacional de Colombia, Colombia

Mario Rueda Beltrán Instituto de

Investigaciones sobre la Universidad y la Educación, UNAM, México

José Luis San Fabián Maroto

Universidad de Oviedo, España

Jurjo Torres Santomé, Universidad de la Coruña, España

Yengny Marisol Silva Laya

Universidad Iberoamericana,

México

Ernesto Treviño Ronzón

Universidad Veracruzana, México
Ernesto Treviño Villarreal

Universidad Diego Portales

Santiago, Chile

Antoni Verger Planells

Universidad Autónoma de

Barcelona, España

Catalina Wainerman

Universidad de San Andrés, Argentina

Juan Carlos Yáñez Velazco

Universidad de Colima, México

arquivos analíticos de políticas educativas

conselho editorial 
Editor Consultor: Gustavo E. Fischman (Arizona State University)

Editoras Associadas: Kaizo Iwakami Beltrao, (Brazilian School of Public and Private Management - EBAPE/FGV, Brazil), Geovana Mendonça Lunardi Mendes (Universidade do Estado de Santa Catarina), Gilberto José Miranda, (Universidade Federal de Uberlândia, Brazil), Marcia Pletsch, Sandra Regina Sales (Universidade Federal Rural do Rio de Janeiro)

\author{
Almerindo Afonso \\ Universidade do Minho \\ Portugal \\ Rosanna Maria Barros Sá \\ Universidade do Algarve \\ Portugal \\ Maria Helena Bonilla \\ Universidade Federal da Bahia \\ Brasil

Rosa Maria Bueno Fischer
Universidade Federal do Rio Grande
do Sul, Brasil
Alice Casimiro Lopes
Universidade do Estado do Rio de
Janeiro, Brasil
Suzana Feldens Schwertner
Centro Universitário Univates
Brasil
Flávia Miller Naethe Motta
Universidade Federal Rural do Rio de
Janeiro, Brasil

\begin{abstract}
Alexandre Fernandez Vaz
Universidade Federal de Santa

Catarina, Brasil
\end{abstract}

\section{Regina Célia Linhares Hostins \\ Universidade do Vale do Itajaí, \\ Brasil}

Alfredo Macedo Gomes
Universidade Federal de Pernambuco
Brasil

Jefferson Mainardes

Universidade Estadual de Ponta

Grossa, Brasil

\section{Jader Janer Moreira Lopes \\ Universidade Federal Fluminense e \\ Universidade Federal de Juiz de Fora, Brasil

Debora Nunes
Universidade Federal do Rio Grande do Norte, Brasil}

\section{Alda Junqueira Marin \\ Pontifícia Universidade Católica de \\ São Paulo, Brasil}

Dalila Andrade Oliveira

Universidade Federal de Minas

Gerais, Brasil
José Augusto Pacheco

Universidade do Minho, Portugal

Jane Paiva

Universidade do Estado do Rio de Janeiro, Brasil

Paulo Alberto Santos Vieira

Universidade do Estado de Mato

Grosso, Brasil

Fabiany de Cássia Tavares Silva Universidade Federal do Mato

Grosso do Sul, Brasil

\section{António Teodoro}

Universidade Lusófona

Portugal

Lílian do Valle

Universidade do Estado do Rio de Janeiro, Brasil

\author{
Alfredo Veiga-Neto \\ Universidade Federal do Rio Grande \\ do Sul, Brasil
}

